\title{
TOURISM DECISION MAKING AND THE EFFECT OF SATISFACTION IN AGRO TAMBI TOURISM
}

\author{
Faishal Permana ${ }^{1}$ \\ Student of Magister Management Agribusiness, \\ Universitas Gadjah Mada (UGM), Indonesia. \\ (Email: permanafaishal@gmail.com) \\ Masyhuri $^{2}$ \\ Lecturer of Magister Management Agribusiness, \\ Universitas Gadjah Mada (UGM), Indonesia. \\ Any Suryantini ${ }^{3}$ \\ Lecturer of Magister Management Agribusiness, \\ Universitas Gadjah Mada (UGM), Indonesia.
}

Received date: 25-06-2019

Revised date: 07-07-2019

Accepted date: $26-07-2019$

Published date: 11-09-2019

To cite this document: Permana, F, Masyhuri \& Suryantini, A (2019). Tourism Decision Making and The Effect of Satisfaction in Agro Tambi Tourism. Journal of Tourism, Hospitality and Environment Management, 4(16), 56-69.

DOI: $10.35631 / J T H E M .416005$

\begin{abstract}
Agrotourism in Indonesia is one of the interesting destinations to be visited by tourists, which encourages PT Perkebunan Tambi which focuses on tea production to create a business line to increase revenue for the company through the establishment of Agro Tambi Tourism in 2001. Understanding the consumer characteristics of Agro Tourism that are different from consumers of tea products, causes the need for further study. Improving Service Quality is important to increase customer satisfaction. Increasing satisfaction lead the willingness of customer to recommend it to others. The purpose of this study is to understand tourists perception of the decision-making process, knowing the tourist's satisfaction and to examine the effect of decision-making process toward satisfaction that is the willingness to recommend Agro Tambi Tourism. The basic method in this research was used descriptive analysis method, Customer Satisfaction Index and regression analysis. A survey by nonprobabilistic sampling was carried out to collect data, and 100 tourists observed as respondent. SPSS 17 was used to analysis those data. The results of the study showed that tourists perceptions were based on the benefits of travel. The Customer Satisfaction Index was 82.25 percent, which stated that tourists were very satisfied, and 88 percent of tourists agreed to recommend Agro Tambi Tourism. Source of information, travel expense, and advantage of travel had a significant influence on the willingness of tourists to recommend Agro Tambi Tourism to family and friends. Agro Tambi Tourism must provide activities that can increase the benefits and satisfaction of tourists. Thus, the recommendations to family and friends lead to reduced marketing costs for Agro Tambi Tourism.
\end{abstract}


Keywords: Agrotourism, Decision-making, Tourist Satisfaction, Recommend Agro Tambi Tourism

\section{Introduction}

Human needs are not only clothing and food needs but also psychological needs which are key factors in individual welfare. The tourism industry provides a service where fulfilling human psychological needs for recreation can be fulfilled with a number of tourist attractions provided by recreational areas. This makes the tourism industry an industry that will always develop according to the needs of their consumers.

Indonesia has a wide variety of tourist attractions that can be used as a holiday reference for domestic visitors or foreign visitors. Natural beauty characterizes tourism from Indonesia, which has been known by many foreign tourists because of its natural beauty. This makes Indonesia one of the main tourist destinations that raises the theme of nature in the World. Hermansyah et al (2012) stated that the Achievement of Visit Indonesia Year 2010 had experienced an increase amid the problems of global economic conditions. In 2010, tourist visits exceeded the Indonesian Government's target of 7 million visits. This increase makes the tourism industry in Indonesia an industry that has a bright future.

The natural beauty offered as a tourist attraction also makes agricultural-based attractions begin to develop. One of them is Agro Tambi Tourism located in Wonosobo Regency, Central Java Province. Agro Tambi Tourism which is a business unit of PT Perkebunan Tambi which focuses on the production of black tea and green tea, which is located in Wonosobo Regency. The strategic location of Agro Tambi Tourism because it is on the tourist route of the Sindoro Sumbing mountain range or commonly known as the Dieng Plateau. It makes the bargaining position of Agro Tambi Tourism has the advantage of several aspects such as strategic location, lodging availability, natural beauty and some tourist attractions that can be enjoyed by visitors who come to agro-tourism objects.

Visitor satisfaction is the main goal for the sustainability of tourist attractions to be able to develop and improve their quality to be able to meet the needs of tourists who come. Satisfaction obtained by tourists will ultimately affect the willingness of tourists to recommend tourist attractions to friends or relatives (Silvestri, 2015). Psychological factors (Pizam et al., 2009 in Rachmadi, 2016) such as the motivation of visitors to come on a tour and their opinions about the intended tourist attractions make it a concern for tourists to choose which tourist destination. They will go to meet their needs. Motivation behind the visitors to come can be divided into two categories, namely push factors and pull factors (Pitana and Gayatri, 2005; Crompton's, 1979; Uysal et al, 1996). The push factor is personal achievement, satisfaction, rest, adventure, increasing knowledge, going from routine and social interaction, while pull factors are climate and environmental conditions, access to ease of transportation (Van der Veen et al, 2012; Noor and Foo, 2014) and distance of tourist attractions. Abdullah et al (2018) says that four variables only explained 30.9 percent of the variance in tourist satisfaction where the highest predictor was destination image, accommodation service quality and ease of transportation but food image did not have a significant relationship with satisfaction.

Decision making of tourists to visit tourist attractions is basically the same as purchasing decisions, namely spending money to get satisfaction (Hermawan et al, 2012). The decisions of tourists on travel are related to leaving home, to which destination, what to do, how to get there, how much money is needed, how long to stay, where to stay, where to eat, and with 
whom traveling is generally made to use several different approaches. These decision can occur routinely or tourists make decisions quickly without requiring long time, seeking information and evaluating available alternatives to make broader decisions, which generally start from (1) the need or desire to travel, (2) information collection and evaluation, (3) tourism decisions, (4) travel preparation and travel experience, and (5) evaluation of travel satisfaction influenced by (1) tourist profile, (2) travel awareness (3) travel features, (4) destination resources and characteristics. (Pizam et al, 2009 in Rachmadi, 2016; Kotler et al, 2017; Wall et al, 2006).

The process of decision making of tourists to visit Agro Tambi Tourism is influenced by several psychological factors such as tourist motivation both push factors and pull factors, searching for information about Agro Tambi Tourism, brand image of Agro Tourism, travel expenses to be incurred, benefits or advantages in travel and travel satisfaction related to post-purchase behaviour. The response from tourists regarding the decision-making process of the tour was very important to be known by agrotourism management to find out the real motives of the tourists who came. So that you can know the motives of the tourists who come, besides management can also increase the attraction they have to be able to compete with attractions that are close to Agro Tambi Tourism. The influence of each decision-making process on tourist affairs is taken into account in planning strategies for developing Agro Tourism facilities and services based on the experiences felt by Agro Tambi Tourism tourists.

Based on this background, the purpose of this study is to understand tourists perception of decision making process of visiting Agro Tambi Tourism, knowing the tourists satisfaction and to examine the effect of decision making process (pull motivation, push motivation, source of information, brand image, travel expense, advantage of travel) toward satisfaction (the willingness of tourists to recommend Agro Tambi Tourism). The research is expected to help Agro Tambi Tourism enhancing his performance in service and quality.

\section{Study of Literature}

\section{Agro-tourism}

Agro-tourism in terms of agricultural views serves as a unique diversification and quality improvement effort. A new image of agriculture is the application of an agribusiness model, agro-tourism is one of the agribusiness businesses (Utama et al, 2018). Most definitions of Agro Tourism have a general theme that combines elements of agricultural life and elements of the tourism industry. The aim of tourism agribusiness is to involve community members to come to the farm, with the main goal being to increase agricultural income (Centre for Land Research and Development and Agro-climate, 2019) and besides that the main goal of agro tourism is to expand knowledge, recreational experience, and its relationship with business in agriculture (Main, 2015; Astuti, 2014) by providing recreational and education-based costs to tourists. With proper planning and implementation, agro tourism will directly affect agricultural income (Mahaliyanaarachchi, 2017; Lobo et al, 1999 in Utama, 2015). The indirect focus of agro-tourism is to supply products such as livestock, value-added goods (such as sauces and jams) and other agricultural products (Thomas, 2018; Torres, 2003).

\section{Decision-making}

The decision-making process of tourists in choosing destinations can be explained by Correira et al (2008) through three important phases namely pre-decision, decision phase, and postpurchase evaluation phase. Crompton (1993) states that there are three phases of decision making, namely the initial consideration phase, the final consideration phase and the final decision phase. In this study using five levels of decision-making processes, namely 
recognition of needs, information seeking, evaluation of alternatives, purchasing decisions and post-purchase behaviour (Kotler et al, 2017; Wall et al (2006). The process of decision making is closely related to social characteristics such as age, education, income (Nuraini et al, 2015), and previous experience and characteristics of tourist behaviour such as motivation (Muksin, 2018; Correira et al 2008), attitudes and values adopted (Pranita, 2016) including the benefits of travel (Amalia, 2017) and the superiority of tourist attractions (Eryani, 2018). The purpose of the process carried out is to get satisfaction with tourism trips that will affect the intention to make a repeat visit (Rachmadi, 2011).

\section{Service and Quality related to Tourist Satisfaction}

Customer satisfaction depends on a product's perceived performance in delivering value relative to a buyer's expectation. Smart companies aim to delight customers by promising only what they can deliver and then delivering more than they promise (Kotler, 2018). Tourist satisfaction can be measured by indicators of tangible, reliability, responsiveness, assurance, and empathy (Parasuraman, 1998). The use of service quality indicators has been done to determine the quality of tourist experience (Dioko, 2017; Manning, 1995; Atilgan et al, 2003; Silvestri et al, 2015). Customer Satisfaction Index (CSI) is used by Fitrianti (2005) to measure level of satisfaction in Lembah Harau Tourism and Oktaviani et al (2006) to measure level of satisfaction in Pasir Mukti Agro Tourism in Bogor, Indonesia.

\section{Recommending Agro Tourism}

The personal words and recommendations of trusted friends, associates, and other consumer tend to be more credible than those coming from commercial sources, such as advertisements or sales people. One study found that 92 percent of consumers trust recommendations from family and friends above any form of advertising (Kotler, 2018). Azam et al (2017) which states that satisfaction that arises in the end will cause consumers to recommend tourist attractions visited to friends, relatives and others. Kasuma et al (2016) in his research stated that service quality affects tourist satisfaction and causes revisit intention and provides recommendations. Hui et al (2007) also stated in his research that recommending family and friends positively influences the overall level of tourist satisfaction.

Based on the literature review, it is developed a framework (Figure 1) which includes six independent variables (pull motivation, push motivation, source of information, brand image, travel expense, advantage of travel and it is hypothesized that all of six independent variables have positive influence toward dependent variable (satisfaction (willingness to recommend Agro Tambi Tourism). 


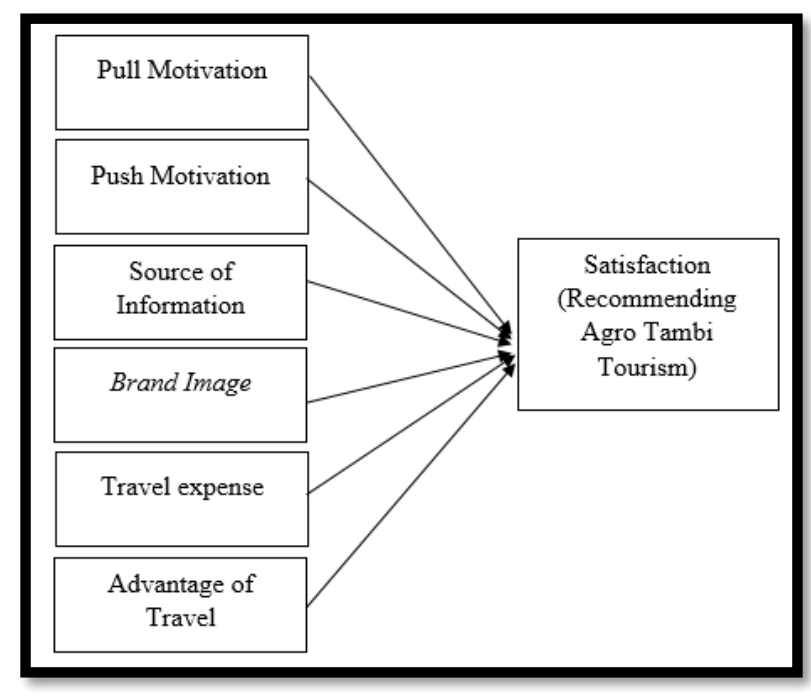

Figure 1: Framework

\section{Research Methodology}

The research was conducted at Tambi Agro Tourism located in Wonosobo District, Central Java Province, Indonesia. Location selection was done purposively because the facilities owned by Agro Tambi Tourism were the most complete infrastructure than similar tourism site in the Central Java province and it was located near Dieng Plateau Tourism Site.

Non probabilistic sampling was used in this research. The number of sample were 100 tourists which were tourists who came to Agro Tambi Tourism. The number of sample was based on Slovin Formula $(n=N /(1+N e 2)$. The total population of tourists was 15,032 people per year and a critical value of 10 percent (error $=\mathrm{e}$ ). The limitation of the sample of this study was tourists aged 17 years or older and stay overnight at Tambi Agro Tourism. This research was conducted in May 2019.

\section{Operational Definition}

The operational definition and measurement of variables used in this study were derived from the decision-making process and dimensions of service quality. The decision making process consisted of the introduction of needs which consist of (Pull Motivation $\left(\mathrm{X}_{1}\right)$ and Push Motivation $\left(\mathrm{X}_{2}\right)$ ), Source of Information $\left(\mathrm{X}_{3}\right)$, Alternative Evaluation (Brand Image $\left(\mathrm{X}_{4}\right)$ ), Purchase Decision (Travel Expense $\left(\mathrm{X}_{5}\right)$ and Advantage of Travel $\left(\mathrm{X}_{6}\right)$ ), and post-purchase behaviour (Satisfaction (Recommending Agro Tambi Tourism )(Y)) (Table 1). This study also used service quality assessment indicators to assess tourist satisfaction consisting of tangible, reliability, responsiveness, assurance, and attention or empathy variables (Table 2). The calculation of the Customer Satisfaction Index (CSI) was as follows (Aritonang,2005 in Oktaviani,2006):

1) The first step was to determine the Mean Importance Score (MIS) and Mean Satisfaction Score (MSS). This value is obtained from the average value of expectations or interests and the average value of performance of each respondent.

$$
M I S=\frac{\sum_{i=1}^{n} Y i}{n} \quad \text { dan } \quad M S S=\frac{\sum_{i=1}^{n} X i}{n}
$$


Information:

$\begin{array}{ll}\mathrm{n} & : \text { Number of respondents } \\ \mathrm{Yi} & : \text { Value of Interest Attribute to i } \\ \mathrm{Xi} & : \text { Attribute Performance Value to i }\end{array}$

2) The second step was to determine Weight Factors (WF). This weight factor is the percentage of MIS values per attribute against the total MIS of all attributes.

Where $=p$ : importance level of attribute $-p$ and $i$ : satisfaction level of attribute $-i$.

$$
W F=\frac{M I S i}{\sum_{i=1}^{P} M I S i} \times 100 \%
$$

3) The third step was to determine a Weight Score (WS). This weight is the multiplication of Weight Factor (WF) with the average level of satisfaction (Mean Satisfaction Score = MSS).

$\mathrm{Ws}_{\mathrm{i}}=\mathrm{Wf}_{\mathrm{i}} \times \mathrm{MSS}_{\mathrm{i}}$

Where = Wfi: Weight Factor of expectations or interests of attribute $-\mathrm{i}(1,2,3 \ldots)$

MSSi: Mean Satisfaction Score of performance attribute - i $(1,2,3 \ldots)$

4) The fourth step was to determine the Customer Satisfaction Index (CSI) with the formula:

Information:

$$
C S I=\frac{\sum_{i=1}^{P} W S i}{5} x 100 \%
$$

P: Attribute to $-\mathrm{p}$

HS: Maximum scale used (Scale 5)

Satisfaction index criteria used a range of scales to indicate the level of customer satisfaction with products and services. The scale of customer satisfaction ranged from 0 100 percent. The scale range formula used based on Simamora (2004) was as follows:

Where: $\quad m=$ Highest score

$$
R S=\frac{m-n}{b}
$$

$\mathrm{n}=$ Lowest score

$b=$ Number of classes or categories created

In this study the range of scales used was:

$$
R S=\frac{100 \%-0 \%}{5}=20 \%
$$

Based on the scale range above, the satisfaction criteria used in this study were:

$0 \%<\mathrm{CSI}<20 \%=$ Very dissatisfied

$20 \%<$ CSI $<40 \%=$ Dissatisfied

$40 \%<$ CSI $<60 \%=$ Quite satisfied

$60 \%<$ CSI $<80 \%=$ Satisfied

$80 \%<$ CSI $<100 \%=$ Very satisfied 
Operational definitions can be seen in Table 1 and Table 2.

Table 1: Operational Definition of Decision Making

\begin{tabular}{|c|c|c|c|c|}
\hline Theory & Indicator & Variable & $\begin{array}{c}\text { Number of } \\
\text { Statement }\end{array}$ & Category \\
\hline $\begin{array}{c}\text { Kotler } \text { et al } \\
\text { (2017) stated } \\
\text { that five levels }\end{array}$ & $\begin{array}{l}\text { Introduction to } \\
\text { Needs }\end{array}$ & $\begin{array}{l}\text { Pull Motivation }\left(\mathrm{X}_{1}\right) \\
\text { Push Motivation } \\
\left(\mathrm{X}_{2}\right)\end{array}$ & 4 & \multirow{5}{*}{$\begin{array}{c}\text { Measured by a Likert } \\
\text { scale } 1 \text { to } 5.1 \\
\text { (Strongly Disagree), } 2 \\
\text { (Disagree), } 3 \text { (Less } \\
\text { Disagree), } 4 \text { (Agree), } \\
\text { and } 5 \text { (Strongly } \\
\text { Agree). }\end{array}$} \\
\hline $\begin{array}{l}\text { of decision- } \\
\text { making }\end{array}$ & $\begin{array}{l}\text { Information } \\
\text { Search }\end{array}$ & $\begin{array}{l}\text { Source of } \\
\text { Information }\left(\mathrm{X}_{3}\right)\end{array}$ & 4 & \\
\hline $\begin{array}{l}\text { processes are } \\
\text { introduction to }\end{array}$ & $\begin{array}{l}\text { Alternative } \\
\text { Evaluation }\end{array}$ & Brand Image $\left(\mathrm{X}_{4}\right)$ & 4 & \\
\hline $\begin{array}{c}\text { needs, } \\
\text { information } \\
\text { search, }\end{array}$ & $\begin{array}{l}\text { Buying } \\
\text { Decision }\end{array}$ & $\begin{array}{l}\text { Travel Expense }\left(\mathrm{X}_{5}\right) \\
\text { Advantage of Travel } \\
\left(\mathrm{X}_{6}\right)\end{array}$ & 1 & \\
\hline $\begin{array}{l}\text { evaluation, } \\
\text { buying decision } \\
\text { and post- } \\
\text { purchase } \\
\text { behaviour }\end{array}$ & $\begin{array}{l}\text { Post-Purchase } \\
\text { Behaviour }\end{array}$ & $\begin{array}{l}\text { Satisfaction } \\
\text { (Recommending } \\
\text { Agro Tambi } \\
\text { Tourism) (Y) }\end{array}$ & 1 & \\
\hline
\end{tabular}


Table 2: Operational Definition of Service Quality

\begin{tabular}{|c|c|c|c|c|}
\hline Theory & Indicator & Variable & $\begin{array}{l}\text { Number of } \\
\text { Statement }\end{array}$ & Category \\
\hline \multirow{13}{*}{$\begin{array}{l}\text { Parasuraman (1988), } \\
\text { states that there are } 5 \\
\text { indicators in calculating } \\
\text { the quality of services, } \\
\text { namely Tangible, } \\
\text { Reliability, } \\
\text { Responsiveness, } \\
\text { Assurance, Caring } \\
\text { (Empathy) }\end{array}$} & \multirow{6}{*}{ Tangible } & Homestay & 5 & \multirow{6}{*}{$\begin{array}{c}\text { Expectations or interests are } \\
\text { measured by a Likert scale of } 1 \text { to } 5 \text {. } \\
1 \text { (very Unimportant), } 2 \text { (not } \\
\text { important), } 3 \text { (less important), } 4 \\
\text { (important) and } 5 \text { (very important) }\end{array}$} \\
\hline & & Lobby & 4 & \\
\hline & & The dining room & 1 & \\
\hline & & Surround area of Homestay & 5 & \\
\hline & & Tea gardens & 1 & \\
\hline & & Tea Factory & 1 & \\
\hline & \multirow{2}{*}{ Reliability } & Promotion and Information & 2 & \multirow{7}{*}{$\begin{array}{l}\text { Performance is something that } \\
\text { visitors feel when visiting agro } \\
\text { tourism, measured by a Likert scale } \\
\text { of } 1 \text { to } 5.1 \text { (strongly disagree), } 2 \\
\text { (disagree), } 3 \text { (less disagree), } 4 \text { (agree) } \\
\text { and } 5 \text { (strongly agree). }\end{array}$} \\
\hline & & Guest Services & 3 & \\
\hline & \multirow{2}{*}{ Responsiveness } & Visitor Advice and Complaints & 2 & \\
\hline & & Responsibility & 1 & \\
\hline & \multirow{2}{*}{ Assurance } & Agro tourism & 2 & \\
\hline & & Packet of Tea and Plantation Tour & 4 & \\
\hline & Empathy & Tourist & 3 & \\
\hline
\end{tabular}




\section{Research Result}

\section{Reliability Test}

The reliability test shows the total of seven variable are indicate higher than 0.7 . According to Ghozali (2018), the questionnaire can be said to be reliable because the value is above 0.7 . It means that all variables are reliable and can be used for next analysis.

Table 3: Reliability Test

\begin{tabular}{|c|c|}
\hline Construct & Cronbach's Alpa \\
\hline Pull Motivation & .742 \\
\hline Push Motivation & .734 \\
\hline Source of Information & .765 \\
\hline Brand Image & .755 \\
\hline Travel Expense & .810 \\
\hline Advantage of Travel & .777 \\
\hline Satisfaction (Recommending Agro Tambi Tourism) & .825 \\
\hline
\end{tabular}

\section{Tourist Characteristics}

Survey results showed the characteristics of the sample taken based on tourists who stayed at Agro Tambi Tourism. The entire sample came on weekends, Saturday and Sunday. 55 percent were male and 45 percent were female. Samples aged 37-46 years were the most and 70 percent of the samples were tourists from the Central Java region. Tourist samples were dominated by samples who had higher education and had income above Rp. 5,000,000. Tourists who come together with the community dominate followed by family groups and as many as 72 percent of tourists were married tourists.

\section{Hypothesis Testing}

\section{Decision Making of Tourist of Agro Tambi Tourism}

Decision making process according to Kotler (2018) are introduction to needs, information search, alternative evaluation, buying decision and post purchase behaviour. Table 4, shows the result of the research.

Table 4: Tourist Perception of the Decision-Making Process

\begin{tabular}{|c|c|c|c|c|c|}
\hline No & Variable & Indicator & Score & $\begin{array}{l}\text { Maximum } \\
\text { score }\end{array}$ & $\begin{array}{c}\% \\
\text { Indicator }\end{array}$ \\
\hline \multirow{2}{*}{1} & \multirow{2}{*}{$\begin{array}{l}\text { Introduction to } \\
\text { Needs }\end{array}$} & Pull Motivation & 1470 & 2000 & 73.50 \\
\hline & & Push Motivation & 1536 & 2000 & 76.80 \\
\hline 2 & $\begin{array}{l}\text { Information } \\
\text { Search }\end{array}$ & $\begin{array}{c}\text { Source of } \\
\text { Information }\end{array}$ & 926 & 1500 & 61.73 \\
\hline 3 & $\begin{array}{l}\text { Alternative } \\
\text { Evaluation }\end{array}$ & Brand Image & 1087 & 1500 & 72.47 \\
\hline \multirow[t]{2}{*}{4} & \multirow{2}{*}{ Buying Decision } & Travel Expense & 288 & 500 & 57.60 \\
\hline & & Advantage of Travel & 1200 & 1500 & 80.20 \\
\hline & Total & & 6507 & 9000 & 72.3 \\
\hline
\end{tabular}

Source: Primer Data processing, 2019 
Based on the results of the research conducted which showed in table 4, tourists who came to Agro Tambi tourism were based on the advantage of travel that would be obtained such as increasing knowledge that could be obtained from tea tour activities which was one of the uniqueness in a tourist destination (Mahaliyanaarachchi, 2017) and the tea-factory tour by 80,20 percent. In addition to being based on perceptions of travel benefits, the perceptions of tourists who came also based on motivation and attractiveness of $76.8 \%$ and $73.50 \%$.

\section{Tourist Satisfaction of Agro Tambi Tourism}

The Mean Importance Score obtained was 142.94 and the Mean Satisfaction Score of 139.71 resulted in a Weight Factor of 100 and a Weight Score of 411.25. Based on the results of the Weight Score obtained then the results are divided into five to determine the visitor satisfaction category. The results obtained were that the tourist satisfaction of Agro Tambi tourism was 82.25 percent which indicated that tourists visiting were very satisfied with the quality of services and facilities provided. The willingness of tourists to recommend is presented in Table 5 .

Table 5: The Willingness of Tourists to Recommend the Site

\begin{tabular}{lcc}
\hline Category & Frequency & Percentage \\
\hline Very Unrecommended & 0 & 0 \\
Unrecommended & 4 & 4 \\
Quite Recommended & 8 & 8 \\
Recommended & 64 & 64 \\
Very Recommended & 24 & 24 \\
\hline Total & 100 & 100
\end{tabular}

Source: Primer Data processing, 2019

As many as 88 percent of tourists recommended Agro Tambi Tourism to family and friends. Azam et al (2017) stated that satisfaction which arising in the end would cause consumers to recommend tourist attractions visited to friends, relatives and others and the desire to make return visits (Kasuma et al, 2016). Hui et al (2007) based on the results of his research stated that recommending tourist attractions to family and friends was positively influenced by the level of tourist satisfaction.

\section{The Effect of Decision-Making Process Toward Satisfaction}

Willingness to recommend and revisit intention are the effect from customer who satisfied with the performance and exceed the expected. However, this study only measured the willingness to recommend which shows in Table 6. 
Table 6: Factors Affecting Willingness to Recommend Agro Tambi Tourism

\begin{tabular}{|c|c|c|c|c|c|}
\hline $\begin{array}{l}\text { Dependent Variable: } \\
\text { Satisfaction } \\
\text { (Recommend Agro } \\
\text { Tourism (Y)) }\end{array}$ & $\begin{array}{c}\text { Expected } \\
\text { Coefisien Sign }\end{array}$ & $\begin{array}{c}\text { Coefisien } \\
\text { Regression }\end{array}$ & $\begin{array}{c}\text { Standard } \\
\text { Error }\end{array}$ & t- count & P-Value \\
\hline Pull Motivation $\left(\mathrm{X}_{1}\right)$ & + & 0.055 & 0.29 & 1.898 & 0.061 \\
\hline Push Motivation $\left(\mathrm{X}_{2}\right)$ & + & -0.022 & 0,030 & -0.728 & 0.469 \\
\hline $\begin{array}{l}\text { Source of Information } \\
\left(\mathrm{X}_{3}\right)\end{array}$ & + & $-0.064^{\star *}$ & 0.027 & -2.357 & 0.021 \\
\hline Brand Image $\left(\mathrm{X}_{4}\right)$ & + & -0.011 & 0.035 & -0.323 & 0.747 \\
\hline Travel Expense $\left(\mathrm{X}_{5}\right)$ & - & $-0.144^{\star \star}$ & 0.062 & -2.346 & 0.021 \\
\hline $\begin{array}{l}\text { Advantage of Travel } \\
\left(\mathrm{X}_{6}\right)\end{array}$ & + & $0.160^{* \star *}$ & 0.035 & 4.526 & 0.000 \\
\hline F-count & \multicolumn{5}{|l|}{$7.671 * * *$} \\
\hline $\mathrm{R}^{2}$ & \multicolumn{5}{|l|}{0.311} \\
\hline Adjusted $\mathrm{R}^{2}$ & \multicolumn{5}{|l|}{0.288} \\
\hline Information: & \multicolumn{4}{|c|}{$* *)$ Significant at the level 95\% $(\alpha=5 \%)$} & $* * *)$ Significant at the level $99 \%=(\alpha=1 \%)$ \\
\hline
\end{tabular}

Results Test of influence of the independent variables with the dependent variable used SPSS 17. Regression analysis (Table 6) produces Goodness of Fit $\left(\mathrm{R}^{2}\right)$ of $31.1 \%$. This shows that the dependent variable (pull motivation, push motivation, source of information, brand image, travel expense and advantage of travel) can explain $31.1 \%$ of the variation of the dependent variable (recommendation). The F test carry out produced a calculated $F$ value of 7.671 and a significance value of 0.00 indicated that the independent variables jointly influence the independent variables with a significance level of $99 \%$. The advantage of travel variable has a positive effect at the $99 \%$ confidence level. Source of Information and travel expense have positive effect at the $95 \%$ confidence level.

\section{Discussion}

Based on the results of the research conducted, it showed that $80.20 \%$ tourists who come to Agro Tambi tourism were based on advantage of travel. Gather with family or friends in a gathering that aim to increase social interaction between individuals (Rachmadi, 2016) is a benefit that would be obtained when visiting Agro Tambi Tourism. Relieving stress is also one of the benefits that according to tourists will be obtained when visiting Agro Tambi Tourism as happened in the study of Hermansyah (2012) in Bogor Botanical Gardens where relaxation is a perception of tourists visiting the Bogor Botanical Gardens. The benefits produced are also investigated by Coreira et al (2008) which states that the first satisfaction boost factor is recreational satisfaction, especially concerning evaluation of emotional states associated with personal well-being, such as relieving stress, escaping from routine, physical relaxation, and away from crowds.

Tourist satisfaction is the destination of all tourist attractions. The Customer Satisfaction Index (CSI) is a measure of tourist satisfaction (Alaan, 2016). This study resulted in a CSI of 82.25 percent. It showed that the satisfaction of tourists at Agro Tambi Tourism was categorized as 
"very satisfied". Homestay conditions, packages provided such as plantation tour and environmental quality in Agro Tambi Tourism had provided satisfaction for tourists. 88 percent of tourists wanted to recommend Agro Tambi Tourism to family and friends.

To achieve the aim of confirming the relationship between decision making process and the satisfaction (willingness to recommend), linear regression analysis revealed that the willingness to recommend Agro Tambi Tourism to family and friends was influenced by source of information, travel expense and advantage of travel. Source of Information has a negative coefficient indicating that if source of information increased will decrease willingness to recommend from tourists. It is contrary different from Lamsoo et al (2013) which says that internet can attract tourism activities for emerging country. Kotler et al (2017) says that digital age has spawned a dazzling set of new customer relationship-building tools, from web sites, online ads and videos, mobile ads and apps, and blogs to online communities and the major social media, such as Twitter, Facebook, YouTube, Instagram, and Pinterest. Possible explanation can be that less willingness to recommend Agro Tambi Tourism is because of the completeness of media information makes customer more selective to recommend the Agro Tambi Tourism. The negative coefficient of travel costs shows that if the travel costs incurred by tourists increase when visiting Agro Tambi Tourism, tourists will reduce the willingness to recommend Agro Tambi Tourism. Products that are not good, the price of products that are expensive, locations that are not strategic and promotions that do not exactly affect customer satisfaction (Alaan, 2016). Silvestri et al (2017) states that costs and prestige affect satisfaction of visitor satisfaction. Advantage of travel like increasing knowledge, relieving stress, and going out with friends (Mahaliyanaarachchi, 2017; Rachmadi, 2016; Hermansyah, 2012) has positive coefficient.

\section{Conclusion}

Based on the results of research and discussion, it can be concluded that tourists' perceptions of the decision-making process are based on the stage of the profitability of the trip. Tourist Satisfaction obtained based on the Customer Satisfaction Index (CSI) produces a value of 82.25 percent and 88 percent of tourists want to recommend Agro Tambi Tourism to family and friends. Willingness of tourists to recommend is influenced by source of information, travel expense and advantage of travel.

Agro Tambi Tourism Management must maintain the quality of its service so that potential of potential tourist satisfaction remains high in accordance with what was informed to them beforehand, so that in the end they were pleased to recommend Agro Tambi Tourism to family and friends. This can be used by Agro Tourism Management to do a Word-of-Mouth strategy.

\section{Reference}

Abdullah, S. I. N. W., \& Lui, E. (2018). Satisfaction Drivers and Revisit Intention of International Tourists in Malaysia. Journal of Tourism, Hospitality and Environment Management, 3(9), 1-13.

Alaan, Yunus. (2016). Pengaruh Service Quality (Tangible, Emphaty, Reliability, Responsiveness, dan Assurance) Terhadap Customer Satisfaction: Penelitian Pada Hotel Serela Bandung. Jurnal Manajemen, 15(2), 255-270.

Amalia, Dina. (2017). Faktor Yang Mempengaruhi Proses Pengambilan Keputusan Wisatawan Berkunjung Ke Objek Wisata Religi Masjid Agung Islamic Center Kabupaten Rokan Hulu. JOM FISIP, 4(2), 1-19.

Astuti, Marhani Tri. (2014). Potensi Agrowisata Dalam Meningkatkan Pengembangan Pariwisata". JDP, 51-57. 
Atilgan, Eda., Akinci, S dan Aksoy, S. (2003). Mapping Service Quality in The Tourism Industry. Managing Service Quality, 13(5), 412-422.

Azam, N. R. A. N., Rashid, B., \& Zainol, N. A. (2017). Conceptualizing the Influence of Environmental Knowledge on Perceived Visit Value to Green Resort in Malaysia. Journal of Tourism, Hospitality and Environment Management. 2(5), 1-17.

Baniya, R., Ghimire, S., \& Phuyal, S. (2017). Push and Pull Factors and their effects on International Tourists' Revisit Intention to Nepal. The Gaze: Journal of Tourism and Hospitality, 8, 20-39.

Basiya R., \& Rozak, HA., (2012). Kualitas Daya Tarik Wisata, Kepuasan dan Niat Kunjungan Kembali Wisatawan Mancanegara di Jawa Tengah. Dinamika Kepariwisataan, 9(2), 112.

Correira, A., \& Pimpao, A. (2008). Decision-making Processes of Portuguese Tourist Travelling to South America and Africa. International Journal of Culture, Tourism and Hospitality Research, 2(4), 330-373.

Crompton, John L., \& Ankomah, Paul K. (1979). Choice Set Propositions in Destination Decisions. Annuals of Tourism Research, 20, 462-476.

Dioko, Leonardo A.N. (2017). Residents' Quality of Life and Visitors' Quality of Experience -Revisiting Tourism Carrying Capacity in Macao. Worldwide Hospitality and Tourism Themes, 9(3), 349-360.

Eraqi, Mohammed I. (2006). Tourism Services Quality (TourServQual) in Egypt. Benchmarking an International Journal. 13(4), 469-492.

Eryani, Analis. (2018). Faktor-Faktor Pengambilan Keputusan Wisatawan Untuk Berkunjung Ke Objek Wisata Istana Siak Siri Indrapura Kabupaten Siak Provinsi Riau”, Retrieved February 10, 2018 from https://media.neliti.com/media/publications/31213-ID-faktorfaktor-pengambilan keputusan-wisatawan-untuk-berkunjung-ke-objek-wisata-i.pdf.

Hermansyah, Danu., \& Waluya, Bagja. (2012). Analisis Faktor - Faktor Pendorong Motivasi Wisatawan Nusantara Terhadap Keputusan Berkunjung ke Kebun Raya Bogor - Survei Pada Wisatawan Nusantara yang Berkunjung Ke Kebun Raya Bogor. Tourism and Hospitality Essentials (THE) Journal, 2(1), 245-268.

Hui, Tak kee., Wan, David., \& Ho, Alvin., (2007). Tourists' Satisfaction, Recommendation and Revisiting Singapore. Tourism Management. 28, 965-975.

Kasuma, J., Esmado, M I., Yacob, Y., Kanyan, A., \& Nahar, H. (2016). Tourist perception towards homestay businesses: Sabah experience. Journal of Scientific Research and Development 3(2), 7-12.

Kotler, P., Bowen, John T., Makens, C., \& Baloglu, Seyhmus. (2017). Marketing for Hospitality and Tourism. England: Pearson Education Limited

Kotler, Philip., Amrstrong, G., \& Opresnik, Marc O. (2018). Princilpes Of Marketing. United Kingdom: Pearson Education Limited

Lamsoo, M.S., Niroomand, M., \& Rafsanjani, K.H. (2013). The Role of Marketing on Tourism Industry. International Research Journal of Applied and Basic Sciences, 4 (1), 73-80

Lupiyoadi, Rambat. (2006). Manajemen Pemasaran Jasa. Jakarta: Salemba

Mahaliyanaarachchi, Rohana. (2017). Agri Tourism Segement Of Rural Tourism. Sri langka : Department of Agribusiness Management, Faculty of Agricultural Sciences, Sabaragamuwa University of Sri Langka.

Manning, R.E., Lime, D.W., \& McMonagle, F.M. (1995). Indicators and standards of the quality of the visitor experience at a heavily-used national park. in Vander Stoep, G.A. (Ed.), Proceedings of the 1994 Northeastern Recreation Research Symposium, Saratoga, CA, 10-12 April, Springs, New York, NY, Retrieved January 16, 2019 from https://www.fs.usda.gov/treesearch/pubs/12576. 
Muksin, Dian RM. (2018). Pengaruh Motivasi Terhadap Keputusan Berkunjung Wisatawan di Ekowisata Mangrove Wonorejo Surabaya. Jurnal Administrasi Bisnis. 55(1), 196 -203.

Oktaviani, RW., \& Suryana, RN. (2006). Analisis Kepuasan Pengunjung dan Pengembangan Fasilitas Wisata Agro: Studi Kasus di Kebun Wisata Pasirmukti, Bogor. Jurnal Agro Ekonomi, 24(1), 41-58.

Parasuraman, A., \& Zeithaml, Valarie. (1988). Servqual: A Multiple- Item Scale for Measuring Consumer Perceptions of Service Quality”. Journal of Retailing. 64(1), 12-40.

Pitana, I Gde., \& Diartam I Ketut S. (2009). Pengantar Ilmu Pariwisata. Yogyakarta: Penerbit Andi.

Pitana, I Gde., \& Putu G. Gayatri. (2005). Sosiologi Pariwisata. Yogyakarta: Penerbit Andi.

Pranita, Ade A. (2016). Proses Pengambilan Keputusan Wisatawan Dalam Mengunjungi Taman Agrowisata Bukit Naang Kecamatan Bangkinang Seberang Kabupaten Kampar Provinsi Riau. JOM FISIP, 3(1), 1-12

Purnami, Ni Noman Alit., Suryawardani, O., \& Suamba, I Ketut. (2019). Pengaruh Kualitas Layanan terhadap Kepuasan Pengunjung Agrowisata Bali Pulina Untuk Membentuk Minat Kunjungan Ulang. E-jurnal Agribisnis dan Agrowisata, 8(1), 59-69.

Rachmadi, H. (2016). Model Pengambilan Keputusan Berwisata. Jurnal Media Wisata, 14(2), 396-414.

Silva, C., Kastenholz, E., \& Abrantes, J. L. (2013). Place-attachment, destination image and impacts of tourism in mountain destinations. Anatolia, 24(1), 17-29

Silvestri, Cecilia., Aquilani, B., \& Ruggieri, A. (2015). Service Quality and Cutomer Satisfaction in Thermal Tourism. The TQM Journal, 29(1),55-81.

Simamora, B. (2004). Panduan Riset Perilaku Konsumen. Jakarta: PT. Gramedia Pustaka Utama.

Thomas, A., Moore., A \& Edwards, M. (2018). Feeding Island Dreams: Exploring the Relationship Food Security and Agrotourism in The Caribbean. Island Studies Journal, 13(2).

Torres, Rebbeca. (2003). Linkages Between Tourism and Agriculture in Mexico". Annals of Tourism Research. 30(3). 546-566.

Utama, I Gusti Bagus Rai., \& Junaedi, I Wayan Ruspendi. (2018). Agrowisata Sebagai Pariwisata Alternatif Indonesia. Yogyakarta: Deepublish.

Utama, Rai. (2015). “Agrowisata Sebagai Pariwisata Alternatif”. Retrieved January 25, 2019 from https: //www.researchgate.net/publication.

Uysal, M., Mclellan, R., \& Syrakaya, E. (1996). Modelling Vacation Destination Decisions: a Behavioral Approach. Recent Advances in Tourism Marketing Research, 5. 57-75.

Wall, G., \& Alister Mathieson. (2006). Tourism -Change, Impacts and Opportunities. England: Pearson Education Limited. 